\title{
United States Foreign Policy and United Nations: The Case of the War in Iraq
}

Changrok Soh

(Korea University)

\section{$\langle$ Content $\rangle$}

I . Introduction

П. Historical Review of US-UN Relations

III. Multilateralism and Unilateralism in US Foreign Policy
IV. The Case of War in Iraq: Battle between Sole Hegemony and World Body

V. Conclusion

- Key Words: US Foreign Policy, United Nations, War in Iraq, Unilateralism, Multilateralism

\section{[ ABSTRACT ]}

This paper deals with the unilateralism and inconsistencies in United States foreign policy and its impact on the functions and independence of United Nations. The overall background of the UN and its limitations from its inception are analyzed in relation to the US decisions to arbitrarily intervene or undermine its neutrality, which are exemplified most conspicuously by the war in Iraq. Criticism amounts as the US continues to bypass the mediatory multilateral functions of $\mathrm{UN}$ in a narrow pursuit of economic and political interest. It is also important to note how the lack of coherence in US foreign policy has adversely affected the operation of UN. Thus, this study examines the history of the US-UN relations, and how inconsistency in US foreign policies, from multilateral to unilateral and vice versa, has affected the UN as well as the global society. In addition, the war in Iraq and the chronological story of the battle between the US and the UN is analyzed as the up-most power struggle between the world's sole super power and the world governing body. Finally, this paper discusses the measures for enhancing the independence of the UN. 


\section{Introduction}

At the dawn of the new millennium, the United States is enjoying a pre-eminence unsurpassed by even the greatest empires of the past.1) This article starts with basic precondition that the US has become the world's sole hegemony after the Cold War era: militarily, economically, politically and culturally. The US pre-eminence is coupled with the serious potential of becoming involved and participating in global transformation. As the numerous cases of American involvement in the domestic affairs of other sovereign nations over the past two decades indicated, the US seems to have intent on reinforcing its self-imposed status as the 'world police.'

The US's justification of the war in Iraq was based on its accusation that Saddam Hussein was developing weapons of mass destruction. (However, after a year and a half of inspection, the US still has not found any substantial evidence of such WMD build-up in Iraq). After 9.11, the Bush administration announced war on terrorism and waged strikes against Afghanistan in 2001, linking its terrorist networks to the Saddam Hussein regime. The war in Iraq itself has produced many paradoxes and dilemmas. The process and result of the US war on terrorism will be described later on in this article. More importantly, the US and the UN have confronted each other on justifying war in Iraq in an unprecedented and the most extreme way while the US was preparing for war. The US foreign policy, which linked the war on terrorism to striking Iraq, has also a war without weapons against the UN.

The US foreign policy has impact on the functions and independence of international organizations including the UN. Criticism amounts as the US continues to bypass the mediatory multilateral functions of the $\mathrm{UN}$ in a narrow pursuit of economic and political interest. It is also important to understand how incoherency of the US foreign policy has adversely affected the UN's operations.

Thus, it is important to examine the contradictory elements of multilateralism and unilateralism in the US foreign policy in relation to its treatment of the UN. The US has tended to adopt multilateral or unilateral foreign policy on the basis of national interest. However, given the status of the US as the world's sole super power, the marked incoherency in the US foreign policy has produced political and economic traumas to the

1) The term appears in Henry Kissinger, America at the Apex: Empire or Leader? The National Interest (Summer 2001), p.9. Kissinger stated in his article that, from weaponry to entrepreneurship, from science to technology, from higher education to popular culture, America exercises an unparalleled ascendancy around the globe. Kissinger also concluded that the United States is sufficiently powerful to be able to insist on its view and to carry the day often enough to evoke charges of American hegemony. 
rest of the world as represented by the UN. As such, the US treatment of multilateral organizations has once again become matters of intense debate. ${ }^{2)}$ Coinciding with the end of the Cold War, the combination of self-satisfaction and prosperity has engendered a sense of American destiny.3) As the former US Secretary of State, Henry Kissinger suggests, the US's interpretations on its role as the world's sole hegemony was difficult to elaborate a long-range approach to a global transition and the UN. And therefore, the US, which has experienced dramatic power shifts in the past few decades, had to adopt from diverse foreign policy change from multilateralism to unilateralism and vice versa. And the rest of the world as well as international originations including the UN, also had to experience inconsistent relationships with the US.

Is it the US's incoherency or unilateralism that has brought about unstable functions on the part of the UN? This study will try to prove that the US's incoherency has damaged UN's operations. And further, US's unilateral foreign policy has led UN into a more desperate struggle. The case study of the war on Iraq will be a good example for analyzing US foreign policy shifts and their impact on the international society in general and the $\mathrm{UN}$ in particular.

The war on Iraq will be recorded as the most dramatic power struggle between the US and the UN. Some see the result as an absolute US victory, while others see it differently. Nevertheless, the war on Iraq in 2003, its aim, procedure, aspects, and results are representative of how American national interests and politics have affected the global society and the UN.

On the basis of the foregoing perspective, this study seeks to demonstrate how US administrations have changed its foreign policies from multilateral to unilateral and vice versa. In addition, the present analysis will seek to examine the relationship between the US and the UN by analyzing dispute over the treatment of Iraq between two. Finally, it discusses the future role of the UN in preventing any such conflict between the US and Iraq.

2) Rosemary Foot, S.Neil MacFarlane, Michael Mastanduno, eds., US Hegemony and International Organizations (New York: Oxford University Press, 2002), p.1. The book tells in an insightful essay, although the debate has been a perennial one since America's founding, it reached a particularly high level of intensity in the 1990s.

3) Henry Kissinger, America at the Apex: Empire or Leader? The National Interest (Summer 2001), p.10. Kissinger explains a sense of American destiny as a dual myth. On the left, many see the US as the ultimate arbitrator of domestic evolutions all over the world. On the right, some imagine that the Soviet Union's collapse came about more or less automatically as the result of a new American assertiveness expressed in the rhetoric rather than from bipartisan exertions spanning nine administrations over almost half a century. He also tells that the right side believe, based on this interpretation of history, that the solutions on the world's ills' is American hegemonythe imposition of American solutions on the world's trouble spots by the unabashed affirmation of its pre-eminence. 


\section{П. Historical Review of US-UN Relations}

The history of the US-UN relationship is long and complex.4) The US was deeply involved from the birth of the UN. The idea of creating the League of the Nations, the forerunner of the UN, came from the former US President Woodrow Wilson in the wake of the World War I as a step towards realizing the idea of collective security. Later, on August 14, 1941, the Atlantic Charter, the root of the UN establishment was announced. And through the Dumbarton Oaks Conference, Yalta Conference, and San Francisco Conference, the UN charter was polished and completed. However, World War II broke out amidst these efforts, which in turn transformed the hitherto fore Euro-centric world order to one dominated by the US. The US became a sole super power in the post World War II era, and as a result, the US took the role of the guardian of defeated nations such as Germany and Japan - by means of its strong military power and economic capacity. In the early stage of the UN, the US was considered a guardian angel to other nations. However, with the onset of the Cold War, US support of the organization would be much shorter than many had envisioned.

During the Cold War, the UN was often the site of ideological battles between the US and the former Soviet Union. In the past, the UN was able to act and send troops to nation states only twice, which demonstrates how unwilling the two were to cooperate on matters of collective security. Members of the UN were able to send troops to the Korean peninsula during the Korean War because the Soviet Union left the conference during a discussion session.5) The UN approved the Gulf War in 1990 because former Soviet Union leader Mikhail S. Gorbachev was already cooperating with the US. In both cases the US led the wars with its enormously powerful military troops. ${ }^{6)}$ Moreover, after the collapse of the Soviet Union, the UN had to witness the rise of an unprecedented powerful member state - the US. The US became the world's sole super power with no rivals to compete with.?)

The history of US-UN relationship takes on a new form from the end of the Cold War era. The real tug-of-war between the two started with the issue of American funding. The

4) Kishore Mahbubani, The United Nations and the United States: An Indispensable Partnership, in David M. Malone and Yuen Foong Khong eds., Unilaterelaism and US Foreign Policy (London: Lynne Rienner Publishers, Inc., 2003) p. 140.

5) Changrok Soh, International organizations: Politics of Global Governance (Seoul: Dasan Publishing Co. 2004), p. 116.(in Korean)

6) Soh (2004), p.116-117.

7) Boutros Boutros-Ghali, Unvanquished: A US-UN Saga (London: I.B. Tauris,1999). This book by the former UN Secretary General reveals the bitterness the UN has felt from US, as Mahbubani describe as, a unique perspective of a man who felt injured by the United States. 
US has been seemingly obsessed with reformation of the UN management and dealing with overloaded bureaucracy, overlapping programs, and unedited finances. According to Kishore Mahbubani, the permanent representative of Singapore to the UN, no member state had done as much damage to the UN as the US since the 1980s. When the American media reported on the US-UN relationship, nearly all of the attention was on those financial troubles. The public impression was that the US was doing essentially the right thing in withholding its assessed dues to the UN as an effort to discipline a bloated international bureaucracy. There was also a perception that the US had been overtaxed.8) The public opinion on US funding to the UN took an important role on US's withholding its dues to the UN. Public perception, however, is of course not as essential as the variant policy orientations of each US administration toward the UN. The recent funding dispute between the UNFPA (United Nations Population Fund) and the US reflect the typical pattern of financial disputes the US and UN have experienced over the years.9)

This dispute shows how the character and beliefs of US administration would act toward the UN and its affiliated organizations. The US played a leading role in global population affairs in 1965 when USAID (United States Agency for International Development) first funded international family planning programs. However, President Reagan and President Bush Sr. denied the importance of the population program and spoke out against the value of family planning services. Although congress defended family planning funding in 1980's, the Reagan administration reserved decades of US leadership on population and family planning by calling for no intervention at the $1985 \mathrm{UN}$ Population Conference in Mexico City. Also, in line with its anti-abortion position, the Reagan and Bush Sr. administrations stopped funding organizations that supported abortion with non-US funds. This policy, know as Mexico City Policy, cut tens of millions of dollars of annual support for the two of the largest international family planning organizations: UNFPA and IPPF(International Planned Parenthood Federation).

After the 1992 US presidential election, the Clinton administration began to question this approach and abruptly altered the politics of population that prevailed in US administration over the past twelve years. On his second day in office, the US President Clinton rescinded the Mexico city policy and cleared the way for US funding of UNFPA and IPPF. And the two years following the 1994 International Conference on Population and Development (ICPD), held in Cairo, the Clinton administration led the donor

8) Kishore Mahbubani, US Doesn't Bear Excessive Share of UN Costs, Wall Street Journal, October 30, 1986.

9) Shepard Forman and Romita Ghosh, The Reproductive Health Approach to Population and Development,Center on International Cooperation, New York University, pp 7-29. 
community in financial support of ICPD agendas. The US provided more than 600 million dollars both in 1995 and 1996. This contribution represented 49 percent and 47 percent of all international population assistance in 1995 and 1996, respectively. However, in November 2001, George Bush Jr. sworn in and he held off authorizing a 34 million dollar US contribution to UNFPA for curtailing illegal abortion in underdeveloped countries, especially in China. ${ }^{10)}$

This case suggests that funding, as well as its military and political power, is a modern weapon that the US holds to exercise control over the UN. And the pattern continues.

One US Senator, Adlai E. Stevenson, testified on the United Nations in 1963:

The United States does not own or control the United Nations. It is not a wing of the State Department. We are no more and no less than the most influential of the 110 members. If we were less, we would be failing to exert the influence of freedom's leaders; if we were more, we would destroy the effectiveness of United Nations, which depends precisely on the fact that it is not an arm of the United States or of any other government, but a truly international organization, no better or worse than the agreement which can be reached by the compelling majorities of its members. $\left.{ }^{11}\right)$

This statement in 1963 suggests that there were times when both the US and the UN took each other to be equal partners. However, the US, the largest stakeholder of the UN and the international society, does not hesitate to exercise its power over the UN as well as the international society militarily, politically and economically.

10) Bound to Gag, Economist, January 26, 2002. In this article, the Economist harshly attacks the Bush administration's UN funding policy as saying, UNFPA, the main family-planning agency, thinks poor people need 950 million dollars worth of contraceptives this year, with another 4 million spent on delivering them. They get nowhere that amount..Some Republicans claim the agency is supporting coercive abortion in China, There is no hard evidence to support this..America's abortion war has done a rich country little good; the poor world deserves it still less. The confronting argument between the conservatives and progressives is not a main concern of this analysis. The point is that one person, usually the US President, whether on this person's belief or his political interest, controls the fate of 340 million dollars that would have been used to deliver family planning tools, maternal health programs and family health education, among other things.

11) This statement is cited in Edward Luck, ed., Mixed Messages: American Politics and International Organizations (Washington, Brookings Institution, 1999), p. 20. 


\section{Multilateralism and Unilateralism in US Foreign Policy}

The post-Cold War era has naturally led the US to the only hegemonic state status. Since 1990s, the US has practiced both unilateral and multilateral foreign policy towards the UN. And whilst practicing its politics, the US oscillated between going it alone in favor of national interests and joining the others for the sake of international cooperation. Each set of politics, in turn, has had different justifications, which generate and help to explain divergent attitude and judgments about the appropriate role of unilateral and multilateral US foreign policy.12) In adopting and practicing foreign policies among US policy makers, whether to guard international interests through multilateral strategies or to protect national interests by unilateral strategies, would have been and will remain to be a difficult question. Both US policy makers and the public understand that the nation is not immune from global developmentsthere is definitely the perception that the US is vulnerable to international threats and that sustained multilateral cooperation is essential in confronting them.13)

Thus, for US policy makers, since the collapse of the former Soviet Union, the bottom line of the debate has been about whether the US should act alone or with others. 14) The US has shifted its foreign policy from the basis of multilateralism to unilateralism and vice versa. Moreover, the US has witnessed dramatic power changes over the past fifteen years, which has tended to reinforce inconsistency in the US foreign policy.

It must be noted, however, that sometimes, the US foreign policy does not reflect its intention of being multilateral or unilateral as clear as is expected. American unilateral actions in a multilateral society can often cause difficulty in understanding the intention of a leading power. For example, some could see the '6-Party North Korea Nuclear Talks' as a case of a multilateral foreign affair. Systematically, the 6-party talks would be considered as multilateral, since South Korea, North Korea, China, US Russia and Japan are involved in the talks to resolve North Korea's nuclear crisis. However, many academics consider the 6-party talks as a typical model of unilateral power struggle between the US and North Korea. The deadlock of 6-party talks has been caused by negative attitudes of

12) Inhui Park, Theoretical Framework of American Hegemonic Strategy in Unipolar Era: Multilaterlan vs Unilateralism, Korean and International Politics, Vol.19, No. 3, p55.(in Korean)

13) Stewart Patrick, Multilateralism and Its Discontents: The Causes and Consequences of U.S Ambivalence. In Stewart Patrick and Shepard Forman ed., The Multilateralism and US Foreign Policy (London: Lynne Rienner Publishes, Inc. 2002). p.1-9. In this study, Patrick explains that, for past decade, US policy makers and pundits have debated the appropriate role of US in a single-superpower world and the best means to advance US objectives within it.

14) Patrick also uses the term alone or with others as an exact description of unilateralism and multilateralism by quoting from Tucker's Alone or With Others. 
the US and North Korea. North Korea repeatedly demanded direct talks with the US. However, the US not only refused to talk with North Korea but also repeated its position that North Korea must meet international demands for cooperating with nuclear inspection. In addition, Washington has reportedly boosted its surveillance of North Korea and lauded its voice on North Korea's nuclear development. ${ }^{15)}$ As a result, the 6-party talks have been deadlocked for months and although South Korea and China are eager to find clues to solve such a stalemate, the situation so far, is worsening.

US's skepticism about international cooperation is not surprising. Great powers rarely make great multilateralists. ${ }^{16)}$ Most would agree. However, the power shift in the US politics has brought about tremendous effects to international society as American foreign policy went back and forth in a short period of time - too short for the international society to adjust itself.

The Clinton administration's foreign policy could be described as assertive multilateralism. The Clinton administration, however, did not always espouse a multilateralist foreign policy. In the wake of the Rwanda Genocide in early 1990s, the Clinton administration kept its silence until 500,000 Tuches were killed. In the latter 1990s, UN Secretary General Koffi Annan had to apologize to Rwandan officials for having been incompetent. It is true that the UN failed to deal with the genocide in Rwanda effectively and many have questioned that, if the US had had great interests in Rwanda as it had in the Balkan Peninsula or the Middle East, the UN would have been able to respond more effectively, greatly reducing the sacrifice.17) The Clinton Administration has also been accused of being political by attacking Iraq on the eve of President Clinton's impeachment voting and, by attacking Kosovo with the intention of toppling Slovodan Milosevic.

However, as earlier mentioned, the US skepticism about international cooperation is unsurprising. Great powers rarely make great multilateralists. The Clinton Administration did, for the most part, adopt and deliver multilateral foreign policy in general. As Korean scholar Lee Sam-sung suggested, ${ }^{18)}$ the key members of the Clinton Administration have

15) Reuters, September 30, 2004.

16) Stewart Patrick, Multilateralism and Its Discontents: The Causes and Consequences of U.S Ambivalence. in Stewart Patrick and Shepard Forman ed., The Multilateralism and US Foreign Policy (London: Lynne Rienner Publishes, Inc. 2002).

17) Various reports on the Rwandan Genocide, accusing the US and UN, especially one titled Leave None to Speak in 1998, A civilian report to UN, elaborates on the consequences of the Rwanda crisis and criticize the political apathy of US and UN.

18) Samsung Lee, The World and America: Reflecting on the $20^{\text {th }}$ Century and Envisioning the $21 \mathrm{st}$ Century (Seoul: Hangilsa Publishing Co.Ltd., 2001) (in Korean). In various publications, Lee Sang-sung continually criticizes the US of being extremely unilateral in international society. However, Lee also says in his books that the Clinton Administration practiced complex mix of realism and liberalism. 
struggled with realistic and liberalistic perspectives in conducting foreign policy. The administration's so- called 'assertive multilateral policies' were often criticized by the conservatives. However, its multilateralism did lead to foreign policy successes for the administration, as tensions reduced on the Korean peninsula and in the Middle East. ${ }^{19}$ )

The relationship between the Clinton Administration and the UN also carried a mixed character. In 1998, when Clinton Administration began striking Yugoslavia over the Kosovo crisis, Clinton preferred to work with NATO allies rather than with member of the UN. The UN peace operations in the 1990s had been transformed both in number and in purpose. Increasingly, UN forces were sent to provide humanitarian relief, to usher in new political arrangements after long wars, or to facilitate the cessation of hostilities. ${ }^{20}$ ) However, in practice, UN missions often confronted with hostile governments and resistant movements as the size and capability of UN peace keepers fell short of complying its missions or managing the authority of the UN. Questions regarding the role of UN peacekeeping were raised among UN officials - Former Secretary General Boutros Boutros-Ghali stated in 1994, Peacekeeping has to be re-invented every day, there are as many types of peacekeeping as there are confrontations. Every major operation provokes a new question. 21) The Clinton Administration, which took a multilateral policy towards international society and the UN, failed to understand or accept the difficulties inherent in the ever-expanding tasks it assigned to the UN and the inherent limits of UN's capabilities.

When the Bush Administration took the helm of US foreign policy, it reversed the course of Clinton's multilateralism and embarked on a singularly unilateral path. With the ascendancy of Neo-Conservatives, the Bush administration believed that, by adopting unprecedented unilateral policy based on unprecedented hegemonic power, it would spread American values to global society. This was coupled with the assessment that its

19) In late 1990 s and year 2000 , the international media was focused on the world's two most dangerous regions. Unarguably, the Clinton Administration did get its own share of applause by supporting South Korean government's Sunshine Policy or Comprehensive Policy toward North Korea. In the late 1990s, from the beginning of South Korea's Kim Dae-jung government, the Clinton Administration has supported South Korea's engagement policy toward the North, which eventually led to the opening of Mt. Kum-kang Tour and the North-South summit in 2000. In addition, Clinton Administration has eagerly sought to resolve the Middle East crisis by urging Israeli Prime Minister Barak and Palestine leader Arafat to participate in a three way talk in the same year. Although the talks failed, this was the last time the world witnessed the three parties at the same table.

20) Sarah B. Sewell, Multilateral Peace Operations, in Stewart Patrick and Shepard Forman eds., The Multilateralism and US Foreign Policy (London: Lynne Reinner Publishers, 2002) p.193.

21) Boutros Boutros-Ghali, School for Advanced International Studies Commencement Address, Federal News Service, May 26, 1994. 
predecessor had undermined US interests making excessive multilateral commitments. ${ }^{22}$ ) This led to its withdrawal from various international treaties, most conspicuously the Tokyo Protocol Treaty. ${ }^{23)}$ Likewise, the administration pursued a missile defense project amidst growing concerns about American unilateralism. And while the international community wrangled over whether or not the US needs to shield itself and its allies with a missile defense system when all major enemies had seemingly fallen.

The world has changed since September 11, 2001 and will not be the same, or at least for a while. The Bush Administration quickly announced the War on Terrorism and waged attacks on suspected terrorist groups and potentially terror-exporting and importing nations. The war in Afghanistan and Iraq came under these circumstances. And with the US's unilateral position on the war on terrorism, a battle against the UN has also become inevitable

\section{The Case of War in Iraq: Battle between Sole Hegemony and World Body}

The War in Iraq will be recorded as the most dramatic power struggle between the US and the UN to date. Some see the result as an absolute victory, one for Bush's unilateralism. The skeptics, on the other hand, have different assessments as they keep faith in the UN as a world governing body and hope to see Iraq well reconstructed under organized international effort led by the UN. Nevertheless, the US ignored the UN Security Council charter while preparing for the war, which also generated international opinion of anti-war movement (the largest one since the Vietnam War), and went ahead with war in Iraq along with its allies, which include the U.K. and Australia.24) The most important thing is that the US was not granted to strike war in Iraq. The US did not get UN authorization to justify the war. The Security Council rejected the war against Iraq.

Some analysts, including Ekaterina Stepanova, see the background of the Bush Administration's unilateral action on Iraq as an unilateral decision based on its predecessor's affairs. Stepanova says that, After a series of controversial and limited

22) David M. Malone, A Decade of US Unilateralism? in David M. Malone, Yuen Foong Khong eds., The Unilateralism and US Foreign Policy (London: Lynne Reinner Publishers, 2002), p. 31.

23) Richard Wolffe and Franced Williams, US Says Bio-Warfare Deal is Unworkable, Financial Times, July 26, 2001. In July 2001, the US withdrew from negotiations on the protocol addressing verification of Biological and Toxin Weapons Convention, declaring that the purposed instrument would not deter other nations.

24) Associated Press, March 5, 2003. 
unilateral strikes against various rogue states, most often Iraq, ${ }^{25)}$ and an even more controversial NATO air campaign against the Federal Republic of Yugoslavia,26) the United States has suddenly found itself supported by most of the rest of the world in building a coalition to mount a massive retaliation campaign in response to unprecedented terrorist attacks on the territory of the United States itself.27) This might explain the harsh attitude of the US toward the UN and the international society and going on war despite strong resistance. However, accustomed belief itself would not explain or justify the US unilateral actions against UN while preparing for war.

In September 2001, US Defense Secretary Donald Rumsfeld signaled that the war on terrorism will take long, sustained efforts and will be a war against a shadowy, stateless enemy. ${ }^{28)}$ However, Bush took quicker and clearer actions than many had predicted.

The Bush Administration's war plan was revealed to the public in January 2002 as Bush said in his State of the Union Address that Iraq, Iran, and North Korea form an Axis of Evil. This unprecedented remark came right after the Afghanistan war in which the US had retaliated for 9.11 terror attacks. The war on Iraq went precisely according to Bush's plans despite UN Security Council's strong resistance. Consequently, such American unilateralism fatally damaged UN authority.

Throughout 2002, the Bush administration persistently sought to disarm Iraq. The US applied unrelenting pressure on the UN Security Council to send UN Weapons Inspectors, while forcing Iraq to comply with such an inspection completely and willingly. Also, the administration urged the UN inspectors to more thorough searches and faster results. As such, a tremendous amount of pressure was brought to bear on the Chief UN Weapons Inspector for Iraq, Hans Blix. It was later revealed by the media ${ }^{29)}$ that the hawkish leaders in the US government had even proposed ousting Hans Blix from the UN Weapons Inspections team, as he was considered too lenient. ${ }^{30}$ )

In February 2003, Secretary of State Collin Powell represented the US government at a UN Security Council meeting. Powell read a report, which claimed that Iraq had not

25) Even after the Gulf War, US and UK coalition forces often attacked Iraq over its violation of flying in No-Fly Zone.

26) 78 days of air strike against Federal Republic of Yugoslavia, led by US in 1999.

27) Ekaterina Stepanova, The Unilateral and Multilateral Use of Force by the United States, David M. Malone, Yuen Foong Khong ed., The Unilateralism and US Foreign Policy (London: Lynne Rienner Publisher), p.181.

28) Washington Post, September 20, 2001.

29) Associated Press, May 20, 2003

30) The US weapons inspectors searched the weapons of mass destructions in Iraq since Bush's announcement of ending the war on May 1, 2003. However, up until now, US inspectors also failed to find any sign of weapons of mass destruction in Iraq 
complied with the UN resolution and was hiding weapons of mass destruction, including chemical and biological weapons. This report continued that Iraq, therefore, is a great threat to world peace and security and UN must approve a new resolution that will allow taking actions against Iraq. During the presentation, Powell mentioned the name of Saddam Hussein, the now-deposed Iraq leader, approximately two dozen times. However, the report failed to convince 15 council members. Countless arguments on UN charter and Resolution 1441 went on between the US and other council member. And despite aggressive American lobbying toward council members, the majority of members, especially France and Russia, two veto powers, and Germany, an elected member, stood to oppose the war. UN Secretary General Kofi Annan also stood against the war and favored giving more time to the UN Weapons Inspectors. The US accused France, Germany and Russia of staying in the Old Europe mindset and decided not to submit any resolutions. The US decided to take action without UN's approval and instead start the war against Iraq with its allies, the U.K. and Australia.

The US and their allies carried out their first military offense against Iraq on March 20, 2003. The statue of Iraq leader Saddam Hussein in Baghdad was toppled on April 7, 2003, and May 1, 2003, US President Bush announced the liberation of Iraqi people. ${ }^{31)}$ The war in Iraq went on and ended precisely as US had planned. Throughout the entire process, the UN was once again relegated to the sidelines and the Security Council was forced to suffer from yet further damage from the persistence of American unilateralism.

\section{Conclusion}

Henry Kissinger wrote a column in the Washington Post on September 16, 2002:

As the most powerful nation in the world, the United States has a special unilateral capacity on implementing its convictions. But it is a special obligation to justify its actions by principals that transcend the assertions of preponderant power. It can not be in either the American national interest or the world's interest to develop principals that grant every nation an unfettered right of preemption against its own definition or threat to its security ${ }^{32}$ )

31) Iraq War Chronology, Yonhap News, Korea, May 2, 2003.

32) Henry Kissinger, Consult and Control: Byword for Battling the New Enemy, Washington Post, September 16, 2002. 
Unfortunately, the US Bush Administration failed to demonstrate rational attitude at UN Security Council, as Kissinger had advised. There were countless disputes over a point of international law among UN Security Council members. And interpretations and reinterpretations over $\mathrm{UN}$ charters and resolutions have left a fundamental question to the world, that is, what will happen to UN charters in the future? In addition, and more fundamental question is, will the UN ever function as a world governing body?

The US and the UK insisted, based on Resolution 1441, that Iraq has acted material breach and violated international law and therefore Resolution 678, which approved the use of force based of Article 42, should be revived. France, Russia, and Germany insisted that the Security Council, not the US, must exam whether Iraq has acted material breach. Also, the three members argued that Resolution 678 was the result of a specific era and therefore a new UN resolution would be vital to the use of force against Iraq. The three also argued that the expression serious consequences in Article 42 does not warrant an automatic use of force. The confrontation over the interpretation of the UN Charter and resolutions were aggravated. However, the US ignored the confrontation and went on war by its own political, economical and military power.

German newspaper Die Zeit pointed out in an editorial in April 2003 that the UN will not be able to reconstruct post war Iraq. The daily argued that, because of its lack of actual power, the UN is not the most appropriate organization to resolve such a chaotic situation. As the paper had predicted, the UN has not now shown much effort to aggressively participate in Iraq reconstruction project of peacekeeping. UN had pulled its personnel from Baghdad in October 2003 and did not re-dispatch despite calls from the Iraqi interim government. ${ }^{33)}$

Criticism over UN's ability lies not only in its history of power struggle with the US but in the question of its actual power. With no territory or citizen of its own and with only its member states, funding and votes, UN has inherent limitations that have not been overcome and predictably will not be. And as there seems to be no other state to balance American power, its unilateral foreign policy is likely to continue. However, it must be noted that the UN is not an useless gigantic organization. And therefore, rejoice at its death, as neo-conservatives in the Bush Administration declared at the time of war on Iraq, would be a joy for themselves. ${ }^{34)}$ The failure to gain UN resolutions for use the force

33) Washington Post, October 30, 2003

34) An encyclopedia states neo-con, an abbreviation of neo-conservatives, as newly risen US republican power since the beginning of Bush administration. Neo-cons' foreign positions, which have their origin in opposition to the 'new left of the 1960 's, fears over the return of US isolation during the Vietnam War. The linchpins of neo-con are US Vice President Dick Cheney, Defense Secretary Donald Rumsfeld, Deputy Secretary of Defense, Paul Wolfowitz. Neo-cons are 
on Iraq has wounded the US and its allies. And as the world continues to witness, there are endless resistant movements in Iraq. As time passes, the US might realize that unilateralism will cause more costs in delivering action despite certain advantages in promoting national interests. The UN would also realize its ineffectiveness and helplessness through the process and afterwards of war on Iraq. However, the chances of rebuilding and guiding the future of Iraq are still given to it. For that, and for preventing future incidents such as US's unilateral action on Iraq, the UN must be transformed and overcome its inability through reform. More specifically, the UN must aggressively pursue how to revise its charter, which was announced sixty years ago. It must build an organization that reflects the majority opinion of the General Assembly gathering of its 191 member states. This seems to be the least the UN can do for the time being to check US's unilateralism. And finally, UN must be aware of general thought, which might grant courage and motivation for its efforts to rebuild the body, that, if the US is the world's indispensable power, the UN is the world's indispensable institution. Although UN only processes convening and mobilizing power, it also has unmatched legitimacy and authority.

distinguished from traditional conservatives. They believe in US philosopher Leo Strauss's contention that it is US's obligation to protect democracy from barbaric society. And as Kim Lobe of Asia Times in August 13, 2003 wrote, neo-cons, as Irving Kristol once remarked, the liberals who was mugged by reality, have reportedly cheered the death of UN at the time of war in Iraq. 


\section{References}

Associated Press, March 5, 2003

Associated Press, May 20, 2003

Boutros-Ghali, Boutros, School for Advanced International Studies Commencement Address, Federal News Service, May 26, 1994

Boutros-Ghali, Boutros. Unvanquished: A US-UN Saga. London: I.B. Tauris, 1999.

Coate, Roger A. ed. The US Policy and the Future of the United Nations. New York: The Twentieth Century Fund Press, 1994.

Economist. Bound to Gag. January 26, 2002

Falk, Richard A. What Future for the UN Charter System of War Prevention? The American Journal of International Law. Vol.97, No.3 (July 2003).

Foot, Rosemary, MacFarlane, S. Neal, and Mastanduno, Michael, eds. US Hegemony and International Organizations. New York: Oxford University Press, 2002.

Frank, Thomas, M. What Happens Now? The United Nations After Iraq, The American Journal of International Law, Vol. 97, No.3 (July 2003).

Forman, Shepard and Ghosh, Romita. The Reproductive Health Approach to Population and Development. Center on International Cooperation, New York University (2003).

Hass, Ernest B. Beyond the Nation-State: Fundamentalism and International Organization. Los Angeles: Stanford University Press, 1964.

Huntington, Samuel. The Third Wave: Democratization in the Late Twentieth Century. Oklahoma City: University of Oklahoma Press, 1991.

Kissinger, Henry. American at the Apex: Empire or Leader? The National Interest (Summer 2002).

Kissinger, Henry. Consult and Control: Byword for Battling the New Enemy. Washington Post, September 16, 2002.

Lee, Samsung. The World and America: Reflection on the $20^{\text {th }}$ Century and Envisioning the $21^{\text {st }}$ (in Korean). Seoul: Hangilsa Publishing, Co.Ltd., 2001.

Lobe, Kim. Asia Times, August 13, 2003

Luck, Edward ed. Mixed Messages: American Politics and International Organizations, 1919-1999 Washington, D.C.: Brookings Institution, 1999.

Mahbubani, Kishore. The United Nations and the United States: An Indispensable Partnership, in David M. Malone and Yuen Foong Khong eds., Unilateralism and US Foreign Policy. London: Lynne Rienner Publishers Inc., 2003.

Mahbubani, Kishore. US Doesn't Bear Excessive Share of UN Costs. Wall Street 
Journal, October 30, 1986.

Malone, David M. A Decade of US Unilateralism? in David M. Malone and Yuen Foong Khong eds. Unilateralism and US Foreign Policy. London: Lynne Rienner Publishers Inc., 2003.

Nye, Joseph S. US Power and Strategy After Iraq. Foreign Affairs, July/August, 2003. Park, Inhui, Theoretical Framework of American Hegemonic Strategy in Unipolar Era: Multilaterlan vs. Unilateralism (in Korean). Korea and International Politics, Vol.19, No. 3.

Patrick, Stewart. Multilateralism and Its Discontents: The Causes and Consequences of US Ambivalence, in Stewarts Patrick and Shepard Forman eds. The Multilateralism and US Foreign policy. London: Lynne Rienner Publishers, Inc., 2002.

Reuters, September 30, 2004

Ruggie, John Gerald, ed. Multilateralism Matters: The Theory and Practice of an Institutional Form. New York: Columbia University Press, 1993.

Sewell, Sarah B. Multilateral Peace operations, in Stewarts Patrick and Shepard Forman eds., The Multilateralism and US Foreign policy. London: Lynne Rienner Publishers, Inc.. 2002.

Soh, Changrok. International Organizations: Politics of Global Governance (in Korean). Seoul: Dasan publishing, co., 2004.

Stepanova, Ekaterina. The Unilaterl and Multilateral use of Force by United States, in David M. Malone and Yuen Foong Khong eds. Unilateralism and US Foreign Policy. London: Lynne Rienner Publishers Inc., 2003.

Washington Post, September 20,2001

Washington Post, September 30, 2003

Wolffe, Richard and Williams, Frances. US Says Bio-Warfare Deal is Unworkable. Financial Times, July 26, 2001.

Yonhap News, Iraq War Chronology, May 2, 2003 (in Korean). 